\title{
MODELLING OF LEAD REMOVAL BY AN AQUATIC MOSS
}

\author{
R. J. E. Martins*, R. A. R. Boaventura** \\ * Dep. of Chemical and Biological Technology, Superior School of Technology, University of Applied \\ Sciences of Bragança, Campus de Santa Apolónia, 5301-857 Bragança, Portugal \\ (E-mail: rmartins@ipb.pt) \\ ** LSRE-Laboratory of Separation and Reaction Engineering, Faculty of Engineering, University of Porto, \\ Rua Dr. Roberto Frias, 4200-465 Porto, Portugal \\ (E-mail: bventura@fe.up.pt)
}

\begin{abstract}
Aquatic bryophytes are frequently used as biomonitors for trace metals in aquatic ecosystems. Nevertheless, their special characteristics also allow using them as biosorbents to clean industrial wastewaters. As biosorption is a low cost and effective method for treating metal-bearing wastewaters, understanding the process kinetics is relevant for design purposes.

In this study, the ability of the aquatic bryophyte Fontinalis antipyretica to remove lead from simulated wastewaters was evaluated. Three kinetic models (pseudo-first order, pseudo-second order and Elovich) were fitted to the experimental data and compared by the F-test. Previously, the effect on biosorption of parameters such as the initial solution $\mathrm{pH}$, contact time and initial metal ion concentration was investigated. The initial $\mathrm{pH}$ of the solution was found to have an optimum value is in the range 4.0-6.0. The equilibrium sorption capacity of lead by Fontinalis antipyretica increased with the initial metal concentration. For an initial metal concentration of $10 \mathrm{mg} \mathrm{L}^{-1}$, the uptake capacity at equilibrium was $4.8 \mathrm{mg} \mathrm{g}^{-1}$. Nevertheless, when the initial concentration increased up to $100 \mathrm{mg} \mathrm{L}^{-1}$, the uptake of lead was 10 times higher. The pseudo-second order biosorption kinetic model provided the better correlation with the experimental data $\left(\mathrm{R}^{2}=1.00\right)$. The applicability of the Langmuir and Freundlich adsorption isotherms to the present system was also assessed. The maximum lead sorption capacity by Fontinalis antipyretica was $68 \mathrm{mg} \mathrm{g}^{-1}$.
\end{abstract}

\section{Key words}

Aquatic mosses; biosorption; Fontinalis antipyretica; kinetics; lead; removal.

\section{INTRODUCTION}

The increasing environmental contamination by toxic metals is a relevant worldwide occurrence. They are not biodegradable and tend to accumulate in living organisms. The consequences of their presence in aquatic ecosystems to human health, living organisms in water and consumers of contaminated plants or animals are well known (Volesky, 2000). Lead has been recognized as a potentially dangerous pollutant, in the same class as mercury, arsenic and vanadium (Lazaridis et al., 2003). Tackett (1987) reports that lead was found to be markedly toxic to human beings when accumulated in high amounts. An adult ingests between 0.3 to $0.6 \mathrm{mg}$ of lead in his diet and a value close to $10 \%$ is retained in the organism. As a consequence, lead can damage the kidney, liver and reproductive system, brain functions and basic cellular processes (US EPA, 1984).

Lead is released into the environment through waste streams from lead smelting, lead mining and coal combustion, lead-based paints use and lead-containing pipes in water supply systems, and additionally, from pigments, photographic materials, ceramic glazes, automobile batteries and cosmetics manufacturing (Vincent et al., 2001; Vilar et al. 2005).

Thus, the removal of toxic metals and particularly lead from waters is an important environmental issue (Naeem et al., 2007). Traditional methods used for heavy metals removal from aqueous effluents (chemical oxidation or reduction, chemical precipitation, coagulation, complexation) are insufficient to achieve the limits imposed or recommended by national and international water 
regulatory agencies (Al-Degs et al., 2006) or extremely expensive (ion exchange, activated carbon adsorption, electrolytic removal, reverse osmosis). The high capital investment required, as well as the high operating costs, led to increasing the search of low-cost adsorbents to be used instead of activated carbon (Wase and Forster, 1997). Moreover, in these processes, chemicals are not needed and the maintenance requirements are small.

In recent years several methods based on metal-sequestering properties of natural materials of biological origin have been considered for decontamination of metal-enriched waters. The principal mechanism involves the formation of complexes between the metal ion and functional groups in the surface or inside the porous material structure, as amino, amido, carboxyl, phosphate, carbonyl and sulfonate groups. Biosorbents include a great variety of materials such as: agricultural sub-products (soybean and cottonseed hulls, rice straw and sugarcane bagasse) (Marshall and Champagne, 1995), aquatic plants (Martins and Boaventura, 2002), peat moss (McKay and Porter, 1997), activated sludge (Aksu et al., 2002), fungi and bacteria (Zouboulis et al., 2004) and algae (Vincent et al., 2001; Vilar et al., 2005). All these materials are abundant in nature and require little processing.

Since 1990 (Shaw, 1990) aquatic bryophytes were know for exhibiting both sensitivity and tolerance to a wide range of heavy metals. Factors as the inexistence of a barrier to metal absorption and the absence of a cuticle, which increases the direct access of soluble metals to the cytoplasm, make the aquatic mosses an important support for heavy metals removal from contaminated waters.

To our knowledge, the results reported in the literature concerning lead removal by aquatic mosses are quite scarce. Therefore, the study of the biosorption equilibrium and kinetics of lead ions by the aquatic moss Fontinalis antipyretica seems to be a relevant research topic. Lead was the heavy metal chosen to carry out this study because (i) it is present in many industrial effluents and mine drainage waters directly discharged into rivers and lakes and (ii) it is toxic when in excess, inhibiting plant and microorganism growth. The results obtained in this work can be useful for a future application of aquatic mosses in the decontamination of metal-bearing industrial effluents.

\section{MATERIALS AND METHODS}

\section{Lead(II) solutions}

All chemicals were analytical grade and purchased from Merck (Darmstadt, Germany). The lead stock solution was prepared by dissolving an accurate quantity of $\mathrm{PbCl}_{2}$ in deionized water. Other lead working solutions were freshly prepared by diluting the lead stock solution with deionized water. The solution $\mathrm{pH}$ was adjusted by adding $0.1 \mathrm{M} \mathrm{H}_{2} \mathrm{SO}_{4}$ or $0.1 \mathrm{M} \mathrm{NaOH}$, as required.

\section{The biosorbent}

This type of aquatic plants was chosen because their high capacity for assimilating nutrients, toxic organics and heavy metals, which has been related in monitoring programs of rivers water quality. Another's relevant reasons: this material is abundant in nature, require little processing and there is a bit applications in literature about them.

The aquatic moss Fontinalis antipyretica was taken from the Selho River, a tributary of the Ave River in Northern Portugal. The background metal content in mosses was considered to be of natural origin and negligible (sensibly $114 \mu \mathrm{g} \mathrm{g}^{-1}$ ). The samples were rinsed with river water in situ and then in the laboratory with deionized water, selecting only the green parts of the plants. The plants were dried in an oven at $70^{\circ} \mathrm{C}$ for $24 \mathrm{~h}$ and then ground in a RETSCH ZM 100 ultracentrifugal mill at $1400 \mathrm{rpm}$ for approximately 90 seconds. The fraction with particle size between $150 \mu \mathrm{m}-300 \mu \mathrm{m}$ was selected for this study. 


\section{Equilibrium experiments}

Equal amounts of $100.0( \pm 0.1) \mathrm{mg}$ of the biosorbent were accurately weighted and transferred to $100 \mathrm{ml}$ glass bottles and $50 \mathrm{~mL}$ of lead solution with concentration between 10 and $100 \mathrm{mg} \mathrm{L}^{-1}$ was added to each bottle. The bottles were then shaken for $24 \mathrm{~h}$ at constant room temperature $\left(20 \pm 1^{\circ} \mathrm{C}\right)$ using a rotary shaker (P-Selecta Rotabit). Each experiment was performed in duplicate and blank solutions (metal solution without biosorbent) were shaken simultaneously. The contact time was previously determined from kinetic studies, carried out at the same temperature and stirring rate, as that required to attain equilibrium. After equilibrium was reached the liquid phase was separated from the biosorbent by vacuum filtration through $0.45 \mu \mathrm{m}$ Gelman Sciences sterilized membranes, and the supernatant was analysed for the residual lead. The metal uptake was calculated by the equation

$q_{e}=\left(C_{0}-C_{e}\right) /\left(m_{a d s} / V\right)$

where $V(\mathrm{~L})$ is the volume of lead solution, $C_{0}\left(\mathrm{mg} \mathrm{L}^{-1}\right)$ is the initial lead concentration, $C_{e}\left(\mathrm{mg} \mathrm{L}^{-}\right.$

${ }^{1}$ ) is the concentration of lead in solution at equilibrium, and $m_{a d s}(\mathrm{~g})$ is the mass of biosorbent (dry weight).

\section{Kinetic experiments}

The influence of the initial metal concentration and biosorbent dosage on biosorption rate was studied in batch mode.

Erlenmeyer flasks with $100 \mathrm{ml}$ capacity were used in this study, each one containing $50 \mathrm{ml}$ of metal solution of a known initial concentration and a pre-weighted amount of dry biomass. The suspensions were mildly stirred for $300 \mathrm{~min}$ on a rotary shaking machine at $140 \mathrm{U} \mathrm{min}{ }^{-1}$. Biosorption kinetic experiments were performed at constant temperature of $20^{\circ} \mathrm{C}$, metal concentrations of 10 and $100 \mathrm{mg} \mathrm{l}^{-1}$ and biosorbent dosage of $2 \mathrm{~g} \mathrm{~L}^{-1}$. In all cases, the initial $\mathrm{pH}$ was adjusted in the range 5.0-5.2 by adding $0.1 \mathrm{M} \mathrm{H}_{2} \mathrm{SO}_{4}$ or $0.1 \mathrm{M} \mathrm{NaOH}$, as required. Samples were taken from each flask at pre-determined time intervals, starting at $3 \mathrm{~min}$ and ending at $300 \mathrm{~min}$. Then, the solution was filtered $(0.45 \mu \mathrm{m}$ Gelman Sciences sterilized membranes $)$ and the metal concentration in aqueous solution was measured. All the experiments were conducted in duplicate.

\section{Analytical methods}

Lead concentrations in the filtrates were determined by acetylene-air flame atomic absorption spectrometry (AAS, Varian Spectra, model S220). The working parameters of AAS were $5.0 \mathrm{~mA}$ and $217.0 \mathrm{~nm}$, respectively, for current and wavelength, giving a detection limit of $1 \mathrm{ppm}$. The instrument response was checked at predetermined times with $\mathrm{Pb}(\mathrm{II})$ solution standards. Prior to analysis the samples were acidified with concentrated nitric acid, and stored in acid-washed plastic vessels.

\section{THEORETICAL BACKGROUND}

\section{Equilibrium isotherms}

Two of the most commonly used isotherms were fitted to the experimental results obtained in this study, the Langmuir and Freundlich equations.

The Langmuir model assumes that the adsorbent surface is homogeneous and the biosorption energy for each biosorption site is equal. Metal ions sequestration occurs without mutual interactions between the ions adsorbed at the material surface. Langmuir equation can be represented as:

$q_{e}=Q_{\max } b C_{e} /\left(1+b C_{e}\right)$ 
where $C_{e}\left(\mathrm{mg} \mathrm{L}^{-1}\right)$ is the residual metal concentration in solution, $q_{e}\left(\mathrm{mg} \mathrm{g}^{-1}\right)$ is the amount of a metal adsorbed, $Q_{\max }\left(\mathrm{mg} \mathrm{g}^{-1}\right)$ is the amount of metal at complete monolayer coverage, and $b(\mathrm{~L}$ $\left.\mathrm{mg}^{-1}\right)$ is a coefficient related to the heat of biosorption. The initial sorption isotherm curve slope $\left(Q_{\max } b\right)$ indicates the biosorbent affinity for the sorbate.

The Freundlich model is based on an exponential distribution of biosorption sites and energies and takes into consideration the possible occurrence of interactions between the sorbed ions. The Freundlich equation is:

$q_{e}=K_{F} C_{e}^{n}$

where $K_{F}\left(\mathrm{mg}^{1-\mathrm{n}} \mathrm{g}^{-1} \mathrm{~L}^{\mathrm{n}}\right)$ represents the biosorption capacity when metal equilibrium concentration equals to 1 , and $n$ represents de degree of biosorption dependence with equilibrium concentration.

\section{Biosorption kinetic models}

Kinetic models are a significant tool to identify the controlling mechanism of the biosorption process. They can be divided into two main types: reaction and diffusion-based models. Some kinetic models are only concerned with the effect of the observable parameters on the biosorption overall rate. This is the case of the pseudo-first order (Lagergren) (Lagergren, 1898), pseudo-second order (Ho and McKay, 1998), Elovich (Low, 1960) and intraparticle diffusion (Weber and Morris, 1963) models presented below.

Pseudo-first order equation:

$q_{t}=q_{e}\left[1-\exp \left(-k_{1} t\right)\right]$

where $q_{t}, q_{e}, k_{1}$ and $t$ are the concentration of metal ion sorbed at time $t\left(\mathrm{mg} \mathrm{g}^{-1}\right)$, concentration at equilibrium $\left(\mathrm{mg} \mathrm{g}^{-1}\right)$, Lagergren rate constant $\left(\mathrm{min}^{-1}\right)$, and time of reaction ( $\left.\mathrm{min}\right)$, respectively.

Pseudo-second order equation:

$\frac{t}{q_{t}}=\frac{1}{k_{2} q_{e}^{2}}+\frac{t}{q_{e}}$

where $k_{2}$ is the pseudo-second order rate constant $\left(\mathrm{g} \mathrm{mg}^{-1} \mathrm{~min}^{-1}\right)$.

The initial sorption rate, $r_{s}(i)$, can be obtained as:

$r_{s}(i)=\left.\frac{d q_{t}}{d t}\right|_{t=0}=k_{2} q_{e}^{2}$

Elovich equation:

$q_{t}=\frac{1}{b} \ln (1+a b t)$

where $a\left(\mathrm{mg} \mathrm{g}^{-1} \mathrm{~min}^{-1}\right)$ and $b\left(\mathrm{~g} \mathrm{mg}^{-1}\right)$ are empirical model parameters.

Intraparticle diffusion model:

When the diffusion of the metal ions inside the biosorbent is the rate-limiting step, the biosorption data can be fitted by the equation

$q_{t}=k_{d p} t^{1 / 2}$

where $k_{d p}$ is the intraparticle diffusion coefficient $\left(\mathrm{mg} \mathrm{g}^{-1} \min ^{-1 / 2}\right)$. 


\section{RESULTS AND DISCUSSION}

The equilibrium experimental data were fitted to the Langmuir and Freundlich equations by nonlinear regression using the commercial software Fig $P$ from Biosoft (minimizing the sum of the squared deviations between experimental and predicted values).

\section{Effect of pH on lead removal}

The results shown in Fig. 1 illustrate the effect of $\mathrm{pH}$ on $\mathrm{Pb}(\mathrm{II})$ removal by the aquatic bryophyte Fontinalis antipyretica. For $\mathrm{pH}<3.0$ the amount of lead removed is insignificant; this result suggests that the biomass can be regenerated using acidified water. In the $\mathrm{pH}$ range $4.0-6.0$ the $\mathrm{Pb}$ (II) removal remains practically constant and around $97-99 \%$. When the $\mathrm{pH}$ increases, the functional groups in the moss particles (phosphate, carboxyl and amino groups) are loaded negatively, then promoting the subsequent attraction and sorption of cations onto the cell surface.

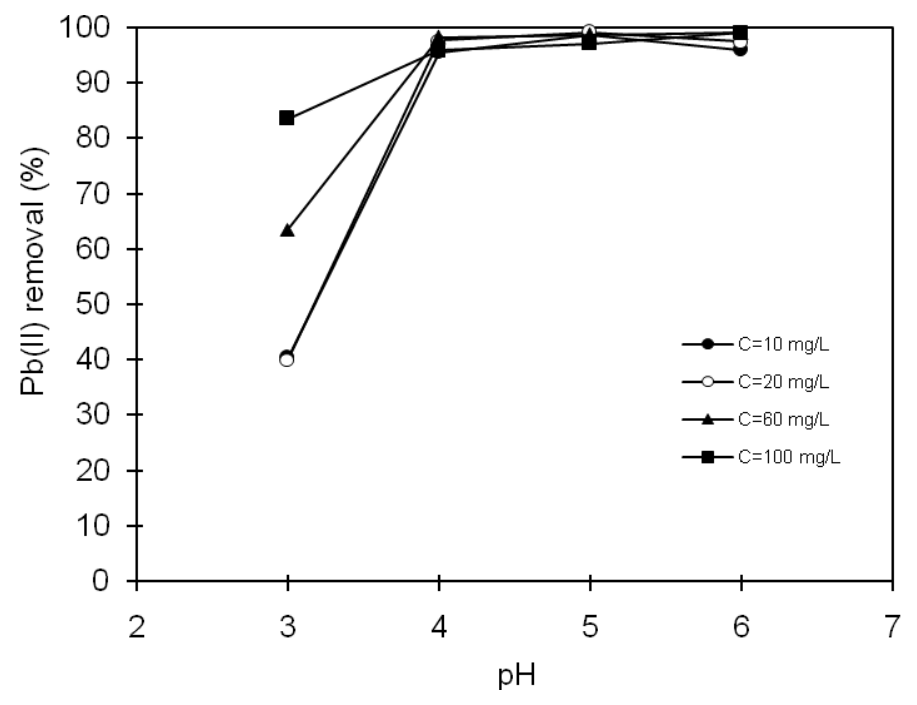

Figure 1. Removal of $\mathrm{Pb}(\mathrm{II})$ from aqueous solutions by aquatic moss Fontinalis antipyretica in the pH range $3-6$.

The same trend was observed by Low et al. [26], when studying the sorption lead from aqueous solutions by spent grain. Nevertheless, at $\mathrm{pH} \geq 7$ insoluble metal hydroxides start precipitating from the solution. In the following work, experiments were carried out at initial $\mathrm{pH} 5.0 \pm 0.2$.

\section{Equilibrium studies}

The biosorption capacity of aquatic mosses for $\mathrm{Pb}$ (II) was evaluated using the Langmuir (Eq. 1) and Freundlich (Eq. 2) isotherms presented in Fig. 2.

The biosorption parameters obtained from the isotherms at the pre-established experimental conditions are shown in Table 1.

The determination coefficients $\left(R^{2}\right)$ presented in Table 1 suggest that Langmuir isotherm describe better the biosorption of $\mathrm{Pb}$ (II) by Fontinalis antipyretica than Freundlich isotherm. However, the most effective way to compare the significant improvements introduced by a correlative model against another is to use the F-Test (Montgomery, 2001). $F_{c a l}$ is defined as the quotient of the variances of the two models in comparison $\left(=S_{\text {Freundlich }}^{2} / S_{\text {Langmuir }}^{2}\right)$, where $S^{2}$ is the model variance. 
In the denominator is placed the variance of the model expected to produce the better fitting. From the variances presented in Table $1, F_{\text {cal }}=5.48$, value to be compared with $F_{\alpha-1}=4.28$ ( $\alpha=95 \%$; f.d.N:D $=5: 5$,). Since $F_{c a l}>1$ and $F_{c a l}>F_{\alpha-1}$ the Langmuir model fits the experimental data better than Freundlich model, and the improvement is statistically significant.

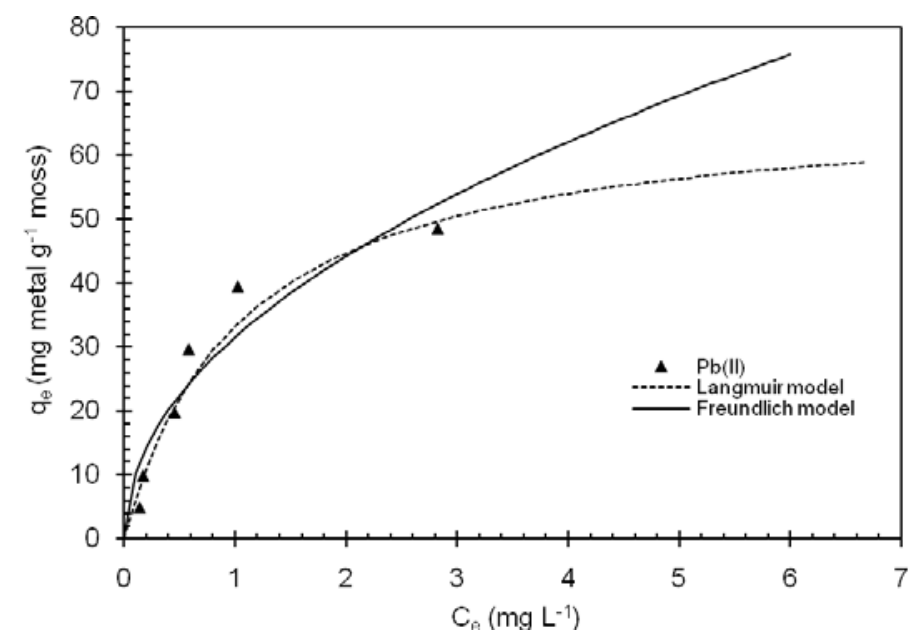

Figure 2. Biosorption isotherms for the system $\mathrm{Pb}(\mathrm{II}) /$ Fontinalis antipyretica $\left(\mathrm{pH}=5.0 \pm 0.2 ; \mathrm{X}_{\mathrm{ads}}\right.$ $=2 \mathrm{~g} \mathrm{l}^{-1} ; \mathrm{T}=20^{\circ} \mathrm{C}$; water hardness $=101.0 \mathrm{mg} \mathrm{CaCO}_{3} \mathrm{l}^{-1}$ ).

Table 1. Langmuir and Freundlich isotherms parameters (average \pm standard error) for lead sorption onto Fontinalis antipyretica at optimum $\mathrm{pH}$.

\begin{tabular}{cccccccc}
\hline & \multicolumn{3}{c}{ Langmuir model } & \multicolumn{5}{c}{ Freundlich model } \\
\hline $\begin{array}{c}\mathrm{Q}_{\max } \\
\left(\mathrm{mg} \mathrm{g}^{-1}\right)\end{array}$ & $\begin{array}{c}\mathrm{b} \\
\left(\mathrm{L} \mathrm{mg}^{-1}\right)\end{array}$ & $\mathrm{R}^{2}$ & $\mathrm{~S}^{2}$ & $\begin{array}{c}\mathrm{K}_{\mathrm{F}} \\
\left(\mathrm{mg}^{1-\mathrm{n}} \mathrm{g}^{-1} \mathrm{~L}^{\mathrm{n}}\right)\end{array}$ & $\mathrm{n}$ & $\mathrm{R}^{2}$ & $\mathrm{~S}^{2}$ \\
\hline $68 \pm 12$ & $1.0 \pm 0.4$ & 0.993 & 3.14 & $30 \pm 5$ & $1.9 \pm 0.4$ & 0.958 & 17.2 \\
\hline
\end{tabular}

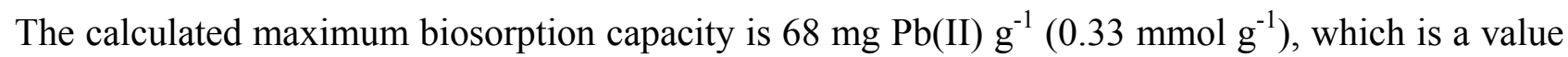
of $Q_{\max }$ that compares favourably with those obtained using other low-cost materials (Table 2).

Such as previously mentioned in the theoretical approach, the initial curve slope $\left(Q_{\max } b\right)$ is one of the most important characteristics of the sorption isotherm. The initial slope calculated from the Langmuir isotherm parameters (Table 1) is $68 \mathrm{~L} \mathrm{~g}^{-1}$, which indicates a biomaterial with high affinity to lead ions in aqueous solution at low concentration. This is an important property when it is obligatory to achieve low concentrations established by water standards. The affinity of this material to lead is greater than that obtained by a natural sorbent (41.2 $\mathrm{L} \mathrm{g}^{-1}$ - Al-Degs et al., 2006) or an algal waste $\left(3.1 \mathrm{~L} \mathrm{~g}^{-1}-\right.$ Vilar et al., 2005). Considering the high biosorption capacity showed by Fontinalis antipyretica, this aquatic bryophyte is promising as biosorvent for the removal and recovery of metal ions of industrial effluents can also be used to recovery valuable metals from aqueous diluted solutions. 
Table 2. Maximum adsorption capacities of $\mathrm{Pb}(\mathrm{II})$ by some low-cost adsorbents.

\begin{tabular}{|c|c|c|}
\hline Adsorbent & $\begin{array}{l}\text { Max. adsorption } \\
\text { capacity }\left(\mathrm{mg} \mathrm{g}^{-1}\right)\end{array}$ & Reference \\
\hline Aquatic mosses (Fontinalis antipyretica) & 68.0 & Present study \\
\hline $\begin{array}{l}\text { Aquatic } \\
\text { demersum) }\end{array} \quad$ macrophyte $\quad$ (Ceratophyllum & 44.8 & (Keskinkan et al., 2004) \\
\hline Sawdust of Pinus sylvestris & 22.2 & (Taty-Costodes et al., 2003) \\
\hline Granulated agar extraction algal waste & 20.5 & (Vilar et al., 2005)) \\
\hline Natural sorbent (quartz, aluminosilicates,...) & 66.2 & (Al-Degs et al., 2006) \\
\hline Cocoa shells & 6.23 & (Meunier et al., 2003) \\
\hline
\end{tabular}

\section{Kinetic studies}

Parameters related to the aqueous solution composition, biosorbent characteristics and the metal ion to be removed certainly influence the mechanism of metal removal by the biosorbent. On the other hand, to design a batch sorption system it is of crucial importance to know the biosorption rate. In this way, it is important to establish the time dependence of such system under various process conditions.

The biosorption rate of lead ions onto Fontinalis antipyretica was determined for initial metal concentrations of 10 and $100 \mathrm{mg} \mathrm{L}^{-1}$. Kinetic data were evaluated using pseudo-first order, pseudosecond order, Elovich and intraparticle diffusion equations (Eqs. 4-8).

Figure 3 (a-c) shows a plot of the experimental results for biosorption of $\mathrm{Pb}$ (II) on Fontinalis antipyretica as a function of time, and the curves predicted by the kinetic models. The corresponding model parameters are presented in Table 3 . These curves are characterized by a strong increase in sorption capacity by the biosorbent during the first 10 minutes, which gradually decreases until saturation. The sorption process is fast and the equilibrium attained in less than $2 \mathrm{~h}$; so, the biosorption of lead involve purely weak intermolecular forces between the mosses and the metal in aqueous solution. Similar equilibrium times were obtained for sorption of lead by Sphagnum moss (Ho and McKay, 2000) and sorption of cadmium and lead by spent grain (Low et al., 2000). When the initial lead concentration increases from 10 to $100 \mathrm{mg} \mathrm{L}^{-1}$, an increase of the same order on the biosorbent capacity is observed (Table 3 ).

From the reaction models employed in this study (Eqs. 4, 5, 7) there is one, the pseudo-second order model, that shows a good compliance on fitting the experimental data $\left(R^{2}=1.00\right)$. The F-Test also indicates that the pseudo-second order model, not only fits better the experimental data than the Lagergren model, but for $95 \%$ probability level, significant difference exists between the two models within the concentration range studied $\left(\alpha=95 \%\right.$; f.d.N:D $=10: 10, \quad F_{\text {cal }\left(P_{1} 1 \text { st } / P 2 n d\right)}=3.05$, $\left.F_{\alpha-1}=2.98\right)$.

Fig. 3d doesn't show a linear relation for the system Fontinalis antipyretica- $\mathrm{Pb}(\mathrm{II})$ during all the biosorption process. According Weber and Morris [25], intraparticle diffusion is involved on the biosorption, but it is not the limitative stage. 
(a)

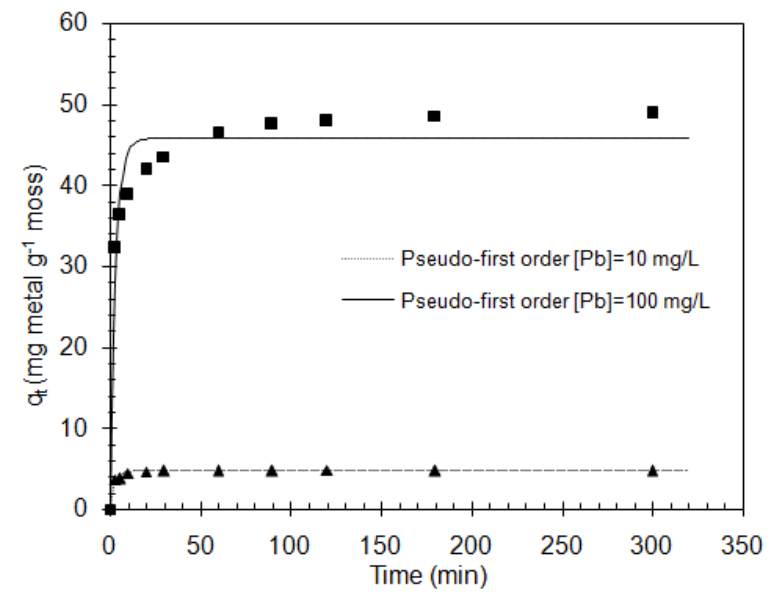

(c)

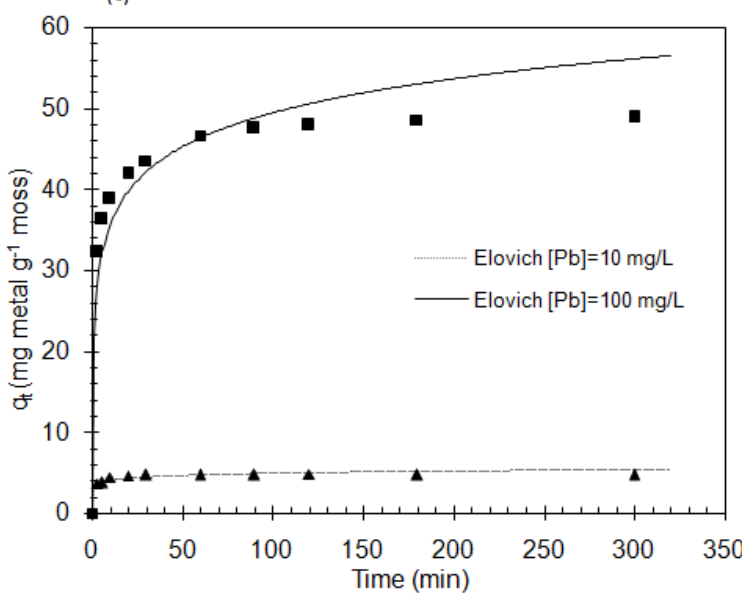

(b)
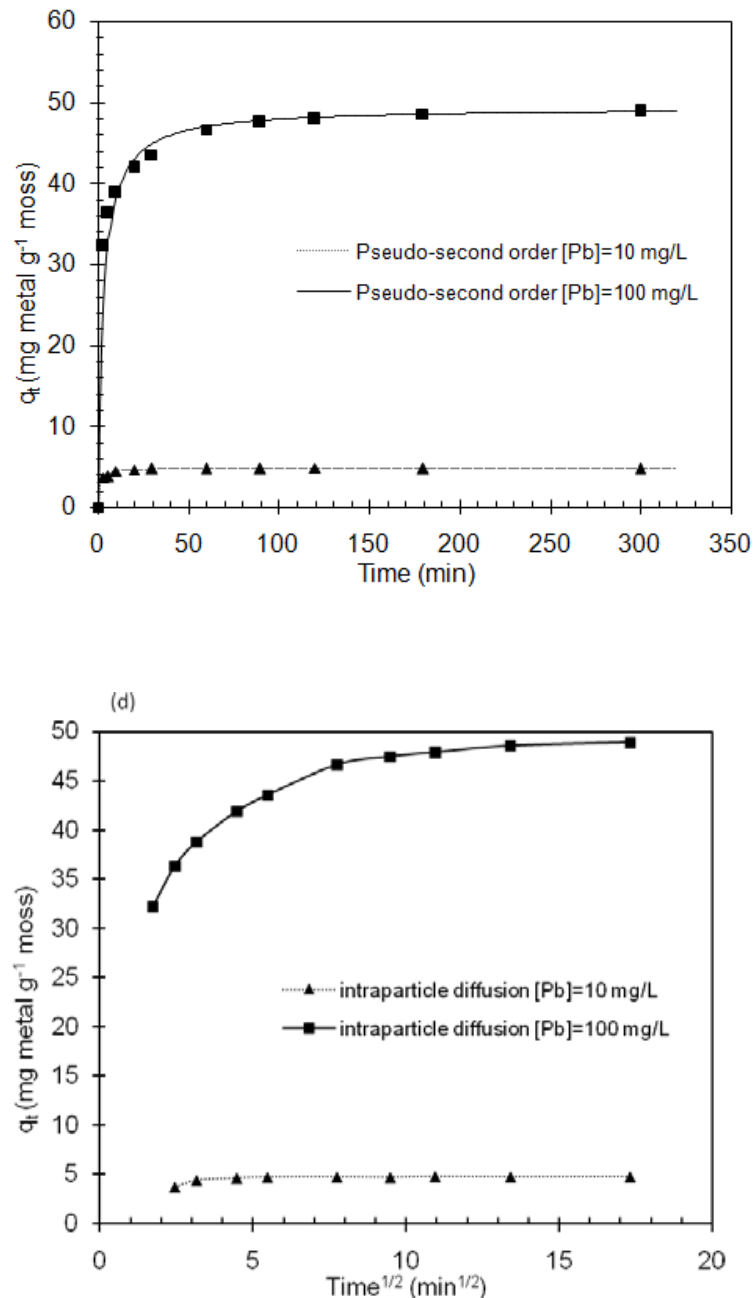

Figure 3. Kinetic modelling of $\mathrm{Pb}$ (II) biosorption by Fontinalis antipyretica: (a) pseudo-first order model; (b) pseudo-second order model; (c) Elovich equation; (d) intraparticle diffusion equation.

Table 3. Kinetic models parameters (average \pm standard error) for the biosorption of lead(II) by Fontinalis antipyretica.

\begin{tabular}{|c|c|c|c|c|c|}
\hline \multicolumn{2}{|c|}{ Pseudo-first order } & $q_{e}\left(\mathrm{mg} \mathrm{g}^{-1}\right)$ & $k_{1}\left(\min ^{-1}\right)$ & $R^{2}$ & $S^{2}$ \\
\hline & $\mathrm{Pb} 10$ & $4.7 \pm 0.2$ & $0.4 \pm 0.1$ & 0.974 & $5.8 \mathrm{E}^{-2}$ \\
\hline & $\mathrm{Pb} 100$ & $46 \pm 3$ & $0.3 \pm 0.1$ & 0.953 & 10.5 \\
\hline Pseudo- & nd order & $q_{e}\left(\mathrm{mg} \mathrm{g}^{-1}\right)$ & $k_{2}\left(\mathrm{~g} \mathrm{mg}^{-1} \min ^{-1}\right)$ & $R^{2}$ & $S^{2}$ \\
\hline \multirow{5}{*}{ Elovich } & $\mathrm{Pb} 10$ & $4.79 \pm 0.03$ & $0.2 \pm 0.1$ & 1.00 & $1.9 \mathrm{E}^{-2}$ \\
\hline & $\mathrm{Pb} 100$ & $49.3 \pm 0.3$ & $0.007 \pm 0.002$ & 1.00 & $2.6 \mathrm{E}^{-4}$ \\
\hline & & $a\left(\mathrm{mg} \mathrm{g}^{-1} \min ^{-1}\right)$ & $b\left(\mathrm{~g} \mathrm{mg}^{-1}\right)$ & $R^{2}$ & $S^{2}$ \\
\hline & $\mathrm{Pb} 10$ & $879 \pm 481$ & $3 \pm 1$ & 0.956 & $9.5 \mathrm{E}^{-2}$ \\
\hline & $\mathrm{Pb} 100$ & $206 \pm 87$ & $0.17 \pm 0.06$ & 0.953 & 13.1 \\
\hline
\end{tabular}


The initial sorption rate $\left(r_{s}(i)\right)$ increased for 5.34 to $16.5 \mathrm{mg} \mathrm{g}^{-1} \mathrm{~min}^{-1}$ when the initial lead concentration increased from 10 to $100 \mathrm{mg} \mathrm{L}^{-1}$. This behaviour is concordant with the removal of copper ions from aqueous solution by tree fern $(\mathrm{Ho}, 2003)$ and lead biosorption by granulated agar extraction algal waste (Vilar et al., 2005). However, the opposite was observed by Ho and McKay when studying the sorption of copper, nickel and lead onto Sphagnum moss peat (Ho and McKay, 2000).

So, the previous facts suggest that chemisorption is the rate-limiting step and the biosorption mechanism follows a pseudo-second order reaction model.

\section{CONCLUSIONS}

The aquatic moss Fontinalis antipyretica, containing various functional groups at the surface or inside the porous material structure, is an effective biosorbent for the removal and recovery of $\mathrm{Pb}$ (II) ions from contaminated waters or industrial effluents. The equilibrium data were better fitted by the Langmuir isotherm than by the Freundlich isotherm, being the improvement attained statistically significant. The maximum removal capacity was determined from the Langmuir equation and found to be $68 \pm 12 \mathrm{mg} \mathrm{g}^{-1}$. The aquatic mosses exhibited a high affinity to lead ions at low concentration. This is an important achievement when it is obligatory to comply with low concentrations of lead established by water standards. The kinetic study of lead ion biosorption on Fontinalis antipyretica led to the conclusion that chemisorption is the rate-limiting step and that the mechanism follows a pseudo-second order reaction model.

\section{REFERENCES}

Aksu Z., Açikel U., Kabasakal E. \& Tezer S. 2002 Equilibrium modelling of individual and simultaneous biosorption of chromium(VI) and nickel(II) onto dried activated sludge. Water Res. 36, 3063-3073.

Al-Degs Y., El-Barghouthi M., Issa A., Khraisheh M. \& Walker G. 2006 Sorption of Zn(II), Pb(II), and Co(II) using natural sorbents: equilibrium and kinetic studies. Water Res. 40, 2645-2658.

Cost and benefits of reducing lead in gasoline. 1984 Draft final report, Office of policy analysis, US EPA 230-03-84-005, Washington DC.

Ho Y. S. \& McKay G. 1998 A two-stage batch sorption optimized design for dye removal to minimize contact time. Trans. IchemE 76, 313-318.

Ho Y. S. \& McKay G. 2000 The kinetics of sorption of divalent metal ions onto sphagnum moss peat. Water Res. 34, 735-742.

Ho Y. S. 2003 Removal of copper ions from aqueous solution by tree fern. Water Res. 37, 23232330 .

Keskinkan O., Goksu M., Basibuyuk M. \& Forst F. 2004 Heavy metal adsorption properties of a submerged aquatic plant (Ceratophyllum demersum). Biores. Technol. 92, 197-200.

Lagergren S. 1898 About the theory of so-called adsorption of soluble substances. K. Sven Vetenskapsakad Handl. 24, 1-39. 
Lazaridis N. K., Jekel M. \& Zouboulis A. I. 2003 Removal of Cr(IV), Mo, and V(V) ions from single metal aqueous solutions by sorption or nanofiltration. Sep. Sci. Technol. 38, 2201-2219.

Low K. S., Lee C. K. \& Liew S. C. 2000 Sorption of cadmium and lead from aqueous solutions by spent grain. Process Biochem. 36, 59-64.

Low M. J. 1960 Kinetics of chemisorption of gases on solids. Chem. Rev. 60, 267-312.

Marshall W. E. \& Champagne E. T. 1995 Agricultural by-products as adsorbents for metal ions in laboratory prepared solutions and in manufacturing wastewater. J. Environ. Sci. Health, Part-A: Environ. Sci. Eng. Toxic Hazard. Subbt. Control 30, 241-261.

Martins R. J. \& Boaventura R. R. 2002 Uptake and release of zinc by aquatic bryophytes (Fontinalis antipyretica L. ex. Hedw.). Water Res. 36, 5005-5012.

McKay G. \& Porter J. 1997 Equilibrium parameters for the sorption of copper, cadmium and zinc ions onto peat. J. Chem. Technol. Biotechnol. 69, 309-320.

Meunier N., Laroulandie J., Blais J. \& Tyagi R. 2003 Cocoa shells for heavy metal removal from acidic solutions. Biores. Technol. 90, 255-263.

Montgomery D. C. 2001 Design analysis of experiments. Wiley, New York.

Naeem A., Westerhoff P. \& Mustafa S. 2007 Vanadium removal by metal (hydr)oxide adsorbents. Water Res. 41, 1596-1602.

Shaw A. J. 1990 Metal tolerance in bryophytes. In Heavy metal tolerance in plants: Evolutionary aspects, Shaw A. J. (ed.), CRC Press, Boca Raton, Florida, p. 133-152.

Tackett S. L. 1987 Determination of methanol in gasoline by gas chromatography: a laboratory experiment. J. Chem. Educ. 64, 14-19.

Taty-Costodes V., Fauduet H., Porte C. \& Delacroix A. 2003 Removal of Cd(II) and Pb(II) ions, from aqueous solutions, by adsorption onto sawdust of Pinus sylvestris. J. Hazard. Mat. B105, 121142.

Vilar V., Sebesta F., Botelho C. \& Boaventura R. 2005 Equilibrium and kinetic modelling of $\mathrm{Pb}^{2+}$ biosorption by granulated agar extraction algal waste. Process Biochem. 40, 3276-3284.

Vincent D., Lawlor A. \& Tipping E. 2001 Accumulation of Al, $\mathrm{Mn}, \mathrm{Fe}, \mathrm{Cu}, \mathrm{Zn}, \mathrm{Cd}$ and $\mathrm{Pb}$ by the bryophyte Scapania undulata in three upland waters of different pH. Environ. Pollut. 114, 93-100.

Volesky B. 2000 Biosorption of Heavy Metals, CRC Press, Florida.

Wase J. \& Forster C. 1997 Biosorbents for metal ions. Taylor and Francis, England.

Weber W. J., Morris J. C. 1963 Kinetics of adsorption on carbon from solution. J. Sanit. Eng. Div. Am. Soc. Civ. Eng. 89, 31-60.

Zouboulis A., Loukidou M. \& Matis K. 2004 Biosorption of toxic metals from aqueous solutions by bacteria strains isolated from metal-polluted soils. Process Biochem. 39, 909-916. 